2. Левин К. Теория поля в социальных науках / К. Левин. - СПб.: Сенсор, 2000. $-368 \mathrm{c}$.

3. Психологические исследования личности: история, современное состояние, перспективы / Отв. ред. М.И. Воловикова, А.Л. Журавлев, Н.Е. Харламенкова. - М.: изд-во “Институт психологии РАН", 2016. - 448 с. (Труды Института психологии РАН).

\title{
СОВМЕСТНОЕ ВЛИЯНИЕ СЕМЕЙНОГО ПОЛОЖЕНИЯ, СТАЖА СУПРУЖЕСКИХ ОТНОШЕНИЙ И СТАТУСА ЖЕНЩИН НА ПОКАЗАТЕЛИ УРОВНЯ СУБЬЕКТИВНОГО КОНТРОЛЯ*
}

Радостева А.Г.

В современной психологии одним из активно развивающихся направлений является психология материнства. В рамках данного направления рассматривается достаточно большой круг вопросов: психологическая готовность женщины к материнству $[1,3,6]$; факторы, влияющие на развитие материнской сферы в структуре личности женщин [8]; изучение психологического состояния беременны женщин [2,3] при нормальной и осложненной патологиями беременности [7,5,9]

Работы, посвященные изучению материнства, демонстрируют, что исследование данного феномена возможно у женщин, ещё не имеющих детей, как этапа прогнозирования будущего материнства; у беременных женщин, как периода становления образа матери и начала реализации родительских установок; у женщин, имеющих детей, как фиксирование складывающегося образа материнства.

Материнство непосредственно связано с готовностью женщины к рождению ребёнка, которая в свою очередь, включает в себя внутреннюю работу, связанную с осознанием своих жизненных задач, готовностью к изменениям структуры семьи и освоению новой социальной роли, а также ответственности и принятию многочисленных обязанностей матери.

Исследования Ю.В. Ковалёвой и Е.А. Сергиенко свидетельствуют, что неосознаваемые представления о материнстве основываются на личностных качествах женщин, их раннем семейном опыте, а также на готовности женщины к специфическому материнскому поведению. Авторы также отмечают, что особенно важным является способность регулировать поведение без излишних усилий и конфликтных переживаний на уровне Я [4].

Отсюда становится очевидной необходимость диагностирования уровня субъективного контроля (уровня интернальности) женщин, сообщающего о способности испытуемых контролировать значимые события своей жизни, быть их автором и причиной, нести ответственность за происходящие с ними события, a не искать объяснения в действиях других людей или обстоятельствах.

Немаловажным фактором в формировании интернальности и придания уверенности в собственных возможностях является семейное положение женщины. 
Интерес к изучению семейных отношений всегда был высок. В современной психологии представлено три основных позиции относительно семейного самосознания:

1. семья, как группа людей, имеющих общие интересы; как среда социализации и развития личности (Е.Е. Сапогова, И.А. Разумова, У.ТарновскаЯкобец)

2. семья, как целостная система, не сводящаяся к сумме её элементов; подчеркивается влияние семейной истории и текущего семейного положения на индивидуальное психическое развитие человека (А.Я.Варга, И.Ю.Хамитова, А.В.Черников, О.А.Карабатова)

3. семья, как атмосфера личного успеха, направляющая на путь индивидуализма (А.Н. Харитонова)

В семейном самосознании женщины можно выделить три компонета: когнитивный - представление о себе как о матери; эмоциональный - оценка себя как родителя, а так же принятие или не принятие ребенка и себя как матери; поведенческая - родительские установки и стиль воспитания.

На сегодняшний день основная масса психологических исследований посвящена супружеским или детско-родительским отношениям, тогда как область личностных характеристик в контексте семейных отношений остается менее изученной.

Таким образом, нам представляется интересным исследование совместного влияние статуса женщины (беременные, имеющие и не имеющие детей) и семейного положения, а также срока брачных отношений на показатели уровня субъективного контроля.

Выборку данного исследования составили 590 женщин, разделенные на три подгруппы: беременные женщины (203 чел.) ( $\mathrm{M}=24,8 ; \mathrm{SD}=4,4)$, женщины, имеющие ребенка возрастом до 5 лет (233 чел.) $(\mathrm{M}=26,2 ; \mathrm{SD}=4,6)$, женщины, не имеющие детей (154 чел.) $(\mathrm{M}=22,4 ; \mathrm{SD}=3,7)$. Возраст испытуемых во всей выборке от 18 до 40 лет ( $\mathrm{M}=24,7 ; \mathrm{SD}=4,5)$.

Семейное положение испытуемых: 369 состоят в браке, что составляет $62,5 \%$; не замужем 119 женщин и это $20 \%$; в разводе - 17 человек или $2,9 \%$ и сожительствуют 85 человек - 14,4\%.

Стаж брачных отношений (для замужних женщин, в том числе и находящихся в сожительстве): из 454 женщин, состоящих в официальном браке или сожительстве, у 295 испытуемых стаж семейных отношений не превышает 5 лет, у 99 - супружеские отношения длятся более 5 лет. 60 испытуемых не указали срок супружеских отношений.

Диагностика личностных свойств испытуемых проводилась с помощью методики «Уровень субъективного контроля» Дж. Роттера (в адаптации Е.Ф.Бажина, Е.А. Голынкиной, Л.М.Эткинда).

Совместное влияние семейного положения, стажа супружеских отношений и статуса женщин на показатели уровня субъективного контроля изучалось с помощью двухфакторного дисперсионного анализа. 
Вывод о совместном влиянии факторов делался в том случае, когда один фактор «вмешивался» во влияние другого фактора на уровень субъективного контроля и изменял направление этого влияния.

Из всех проанализированных показателей уровня субъективного контроля два фактора обнаружили на себе совместное влияние (взаимодействие) факторов семейного положения и статуса. Это оказались показатели 1) общая интернальность $(\mathrm{p}<0,05) 2)$ интернальность в области достижений $(\mathrm{p}<0,04)$.

И только один обнаружил на себе совместное влияние (взаимодействие) факторов стажа семейных отношений и статуса. Это оказался показатель интернальность в межличностных отношениях $(\mathrm{p}<0,001)$.

Результаты анализа общей интернальности свидетельствуют о том, что женщины, не имеющие детей и состоящие в браке имеют значимые различия с группой женщин, не имеющих детей и в браке не состоящих и с беременными женщинами, состоящими в браке. Данные различия сообщают о том, что бездетные замужние женщины ощущают себя более нерешительными, неуверенными, зависимыми от обстоятельств или других людей, а также могут быть эгоистичными и раздражительными. Тогда как замужние беременные женщины и незамужние бездетные обладают более высоким уровнем субъективного контроля, то есть ощущают себя более самостоятельными, решительными, независимыми, дружелюбными, более ответственными за собственную жизнь и события в ней происходящие.

Логика различий в данных группах представляется следующим образом: бездетные незамужние женщины в большей мере предоставлены самим себе, они вольны определять круг своего общения, интересов, планировать время, досуг и т.д. Это и дает ощущение большей свободы, самостоятельности, независимости. Замужние беременные женщины, сосредоточенные на своем состоянии, ощущают ответственность за развитие ребенка. Пока ребенок находится в утробе это дает матери большую свободу (продолжает работать, посещает мероприятия в удобное для себя время, планирует свой режим дня и т.п.). В случае же, когда женщина находится в браке, но ещё не имеет детей, вполне вероятно, что женщина занимает позицию ведомого, отдавая бразды правления супругу. В этом случае женщине приходится приспосабливаться к определенные требованиям мужа ориентироваться на его мнение, отсюда и может возникать ощущение зависимости и несамостоятельности.

По показателю интернальностив области достижений полученные результаты свидетельствуют о том, что замужние женщины не имеющие детей демонстрируют более низкие показатели интернальности в области достижений, в сравнению с незамужними женщинами, не имеющими детей, а так же в сравнении с беременными женщинами с разным семейным положением.

Данные различия говорят о том, что замужние женщины не имеющие детей приписывают свои успехи и достижения обстоятельствам или помощи других людей. Тогда как, незамужние женщины без детей и беременные женщины с разным семейным положением (замужние и незамужние) считают себя источником того, что они имеют в жизни и в своих планах на будущее 
также рассчитывают на собственные силы. Таким образом, различия по показателю интернальности в области достижений вполне согласуется с различиями, полученными в ходе сравнения групп по показателю общей интернальности, а значит в своей интерпретации может опиратся на те же основания.

Результаты анализа по показателю интернальность в межличностных отношенийх свидетельствуют о том, что все группы испытуемых оказались в зоне экстернальности, то есть считают себя ответсвенными за построение межличностных отношений с окружающими. Однако значимые различия были выявлены между группами беременных женщин, состоящих в браке более пяти лет и женщин с детьми, состоящих в браке менее пяти лет с группами беременных, состоящих в браке менее пяти лет, женщин, имеющих детей и состоящих в браке более пяти лет и женщинами, не имеющими детей и состоящими в браке менее пяти лет.

Таким образом, беременные женщины, состоящие в браке более пяти лет и женщины, имеющие детей и состоящие в браке менее пяти лет демонстрируют более выраженное чувство ответственности за установление межличностных контактов.

Данные различия представляется возможным объяснить следующим: беременные женщины, состоящие в браке менее пяти лет, вероятнее всего являются представительницами молодых семей, где установление контакта происходит за счет обоюдного взаимодействия супругов, то есть, возможно, молодые женщины ожидают более активной позиции от супруга и других членов семьи в выстраивании взаимоотношений, с учетом их особого состояния - беременности. В подобной позиции могут находится и женщины, не имеющие детей и состоящие в браке менее 5 лет, то есть в позиции ожидания инициативы установления взаимных контактов от других членов семьи. В то время как беременные женщины, состоящие в браке более пяти лет с большей готовностью берут на себя ответственность за установления межличностных отношений, что связано с их большим жизненным и семейным опытом .

Однако, находящиеся в браке более пяти лет женщины имеющие детей, склонны равноценно делить ответственность за установление межличностных контактов между собой и иными членами взаимоотношений. Что может свидетельствовать об установившихся порядках и распределении меры ответственности в семейных взаимоотношениях. Тогда как женщины, имеющие детей и состоящие в браке менее пяти лет выказывают большую готовность брать на себя ответственность за развитие межличностных отношений, что может быть свидетельством о стремлении взять на себя инициативу в налаживании межличностных контактов между членами семьи.

Таким образом, проведенное нами исследование и полученные выводы свидетельствуют о том, что фактор вступления в брак, а также наличиеlотсутствие ребенка или период ожидания его рождения (беременность) оказывают существенное влияние на проявление интернальности женщин, как существенной части структуры их личности. 


\section{*Исследование выполнео при поддержке Российского Фонда Фундаментальных исследования, проект №17-16-59001 \\ Литература}

1. Баз Л.Л., Баженова О.В., Копыл О.А. Готовность к материнству: выделение факторов, условий психологического риска для будущего развития ребенка. // Синапс, 1993. - № 4. - С. 35-42. ;

2. Брутман В.И., Радионова М.С. Формирование привязанности матери к ребенку в период беременности // Вопросы психологии. 1997. № 7. С. 38-47;

3. Брутман В.И., Филиппова Г.Г., Хамитова И. Ю. Динамика психологического состояния женщин во время беременности и после родов // Вопросы психологии. - 2002. - № 1. - С. 59-68.;

4. Ковалева Ю.В., Сергиенко Е.А. Контроль поведения при различном течении беременности. / Исследования по когнитивной психологии / под ред. Е.А.Сергиенко. - М.: Изд-во «Институт психологии РАН», 2004. с.424-464

5. Коваленко Н.П. Психопрофилактика и психокоррекция женщин в период беременности и родов: Перинатальная психология, медико-социальные проблемы. - СПб, 2001. - 318 с

6. Мещерякова С. Ю. Психологическая готовность к материнству // Вопросы психологии. - 2000. - № 5. - С. 18-27

7. Русалов В.М., Рудина Л.М. Индивидуально-психологические особенности женщин с осложненной беременностью. // Психологический журнал. - 2003. - Т. 24, № 6. - С. 16-27.;

8. Филиппова Г.Г. Психология материнства: Учебное пособие. - М.: Ин-т психотерапии, 2002. - 240 с.

9. Филиппова Г.Г. Психологические факторы нарушения беременности и материнства // Перинатальная психология и медицина: Сборник материалов конференции по перинатальной психологии. - СПб.: Международный институт психологии и управления, 2003. - С. 34-38.

\section{ВЛИЯНИЕ МЕТОДИЧЕСКИХ СРЕДСТВ НА ДИАГНОСТИРУЕМЫЙ УРОВЕНЬ СФОРМИРОВАННОСТИ ИНТЕЛЛЕКТУАЛЬНОЙ КОМПЕТЕНТНОСТИ У МАЛЬЧИКОВ И ДЕВОЧЕК*}

Сиповская Я.И.

Проводя эмпирические исследования проявлений интеллектуальной компетентности, ученые нередко сталкиваются с недостаточностью существующих методических приемов. Часто разрабатываются новые тесты, опросники и прочий рабочий инвентарь. Так поступили и мы, определив компетентность как системно организованный ментальный опыт [9; 11; 17], дающий возможность достичь высоких практических результатов в какой-либо определенной предметной области [1; 4; 16]. При этом в наших исследованиях выделяется интеллектуальная компетентность в качестве базовой, основной, обеспечивающей возможность развития профессиональных, более 